\title{
Validation of Measures of Academic Self- Handicapping Behavior and Student Engagement on Muslim University Students
}

\author{
Hafsa M Mwita ${ }^{a}$, Syed Alwi Shahab ${ }^{b}$, Mohamad Sahari \\ Nordin $^{c}$, \& Ainol Mdziah Zubair ${ }^{\mathrm{d}}$
}

\begin{abstract}
As a preliminary step to studying the reciprocal relationship between student engagement and academic self-handicapping, the present study had the aim of validating two key instruments on the target non-western population. The two instrruments in question were 1) the Self-Handicapping Questionnaire (SHQ 2011), and 2) the Student Engagement Questionnaire (SEQ 2011) which consists of i) the Emotional Engagement Scale, ii) the Behavioral Engagement Scale, and iii) the Cognitive Engagement Scale. We wanted to discover the psychometric properties of these instruments when used on an Asian Muslim population, in a predominantly Muslim setting. Principal Components Analysis (PCA) and Confirmatory Factor Analysis (CFA) were employed. Results indicated that both measures had adequate validity and reliability when used on a Muslim population.
\end{abstract}

Keywords: Academic Self-Handicapping Behavior, Self-Handicapping Questionnaire; Student Engagement Questionnaire; Student engagement

a PhD, SUMAIT University, Zanzibar. Email: hafsa.m.mwita@gmail.com b Associate Professor, Kulliyyah of Education, International Islamic University Malaysia. Email: alshahab@iium.edu.my

c Professor, Kulliyyah of Education, International Islamic University Malaysia.

d Associate Professor, Kulliyyah of Education, International Islamic University Malaysia. 


\section{INTRODUCTION}

Most of the researchers define self-handicapping as student's behavior which involves creating obstacles to successful performance on tasks that the student considers important (Rhodewalt, 1994; and Tice, 1991), and when the student fail he/she looks for excuses. For example, blame the teacher, blame the parents, blame the friends. They express themselves as being lazy or shiftless (Covington, 1992) instead of accepting the fact that they have a lower ability in that particular subject and that they need to exert more effort in order to achieve good grades. This implies that self-handicapping behavior is opposite to student engagement.

In some cases when students fear that they will fail they engage themselves in activities that increase their probability of failure (Urdang, 2004). For example, they procrastinate by engaging themselves with many side activities to the extent of having very little time for their revision and fulfilling their assignments. Self-handicapping students tend to have low self-esteem, increase in negative behavior, lack of academic motivation, lack of student engagement and consequently low achievement. This is also confirmed by Bandura (1986) who claim that learning problems and behavioral problems coexist therefore teachers need to be aware that students with one of these problems are more susceptible to the other problem. Individuals' beliefs about the self are organized and involve beliefs about general or global competence as well as beliefs about specific abilities that are valued by the culture (Lotkowski, et al., 2004).Thus, REBT emphasizes the importance of attending to irrational beliefs that that help to create disturbances in individuals' lives (Sharf,' 2004 p322).

Most of the previous studies on students and teachers have been focusing on students' achievement while students are obliged to engage with the university requirements, lectures' requirements, campus activities, rules and regulations so as to have a successful achievement. The most pressing and persistent issue for students and teachers, according to Newman (1992), is not low achievement, but student engagement. According to Finlay (2006), the engaged student is expected to show sustained behavioral involvement in learning activities accompanied by a positive emotional tone. Multicultural Counselling has shown factors like culture, gender, identity and religion as important 
aspects of wellbeing (Fuertes and Gretchen, 2001; Sue and Sue, 2003; Pederson, 2007).

Previous studies have identified self-handicapping behavior as one of the major academic concerns in both higher and lower institutions (Rhodewalt\& Davidson, 1986; Berglas \& Jones 1978; Higgins \& Hariss, 1988; Shepperd \& Arkin, 1989; Tice \& Baumeister, 1990). Today it is still considered an important concern as commented in Palasigue (2009). "In today's post-modern society, it is getting harder and harder to get the students get engaged in classroom instruction and learning" Many of them want to know how to pass the course and get a better career of their choice if they fail to cope with the course, they may choose to apply various psychological, behavioural and/or physical obstructs (Lazarus $\&$ Folkman 1984). This academic self-handicapping is a severe problem with emerging adults (Jeffrey, 2007 \& Newman 1992) regardless of their nationalities and cultures including the emerging adults from the Muslim world.

Although self-handicapping is evident among tertiary level students, most of the previous studies on self-handicap have been conducted on the primary and secondary school students. For example studies on the influence of the level of academic achievement: - (e.g., MacIver and Epstein, (1993); Blyth Simmons \& Carlton-Ford (1993); Eccles, Wigfield, Flanagan, Miller, Reuman \& Yee (1989); Epstein \& McPartland (1976). Studies on the decrease of self-esteem e.g. Simons \& Blyth, (1987); Wigfield, Eccles, Mac Iven, Ruemsn \&Midgeley(1991); the increase of psychological distress:- (e.g., Chung Elias, and Schneider (1998); Hirsch \& Rapkin, (1987); academic motivation (e.g., Harter, (1981); and (e.g., self-concept: Marsh (1989).

Among the few studies which have been conducted on students of higher institutions, (e.g., Jones and Berglas 1978;Rhodewalt, Morf, Hazlett \& Fairfield, 1991; Seligman, Nolen-Hoeksema, Susan, Thomton, Thomton and Karen, 1990; Zuckerman \& Tsai, 2005; McCrea, Hirt and Milner, 2008; Pulford, Johnson \& Awaida, 2005; Kearns, Forbes and Gardner 2008; Wu, Kee, Lin \& Shu 2009; Sahran, 2011; Martin, Marsh and Debus,1999) however,none of the self-handicapping studies has been conducted in any of the Islamic Institutions.

According to the Council for the Advancement of Standards in Higher Education (CAS, 1999), the mission of university and college 
counselling centres is: "to assist students in defining and accomplishing personal, academic and career goals, by providing developmental preventive and remedial counselling". Hence it is pivotal to investigate significant predictors of academic self-handicapping which will help counsellors and educators, in identifying and rectifying academic selfhandicapping and consequently improve students' academic engagement and achievement.

Many changes experienced among youths have been found to have a negative influence on their efficacy which includes practicing selfhandicapping behavior, reduction in the level of student engagement, decreased self-esteem and increase in psychological distress as noted by Sahranc (2011) who proved a significant relationship between self-handicapping, depression, anxiety and stress similarly Hobden and Pliner (1995) who reported a positive relationship between selfhandicapping and negative emotional mood state.

For Muslims, failure to practice engagement is believed to ultimately lead not only the loss of worldly successes, but also the loss of successes of an afterlife which is of greater importance to them than the present life. Islamic concepts are inculcated in a Muslim's mind from child hood until the last day of his/her existence in this world, yet Muslim youths practice self-handicapping behavior in their day to day life. "Self-handicappers choose obstacles to successful performance that would enable them to find excuses for failure away from their competence and onto the acquired obstacle, in so doing they try to avoid disconfirmation of a desired self-concept" (Rhodewalt \& Davison, 1986).

According to the attribution theory (Weiner, 1974; 1986), individuals have a basic desire to balance their perception of present self with a relevant representative standard or future self-image (Scheier \& Carver, $1998 ; 1982 ; 1983 ; 1985)$. Hence, incongruence between how the young adult pursue self and the aspirations pursued may lead the student to maladaptive externalizing behaviours including self-handicapping behavior. By studying what is academic self-handicapping, why people self-handicap and how they self-handicap, counsellors, psychologists and educators can help the handicappers to rectify their negative behavior and solve their existing behavioural problems, in a less destructive way. 
Student engagement is related to academic self-handicapping which scholars like Knee and Zuckerman, (1998), Rhodewalt (1994), and Berglas (1985) have reported to be associated with a variety of stable characteristics such as low self-esteem, low perception of control, high self-consciousness and a belief that intelligence is a fixed trait. All these afore mentioned characteristics indicate defensive pessimism which is a cognitive strategy involving setting unrealistically low expectations and thinking of worse outcomes even though one has experienced success in the past (Norem \& Counter, 1986).

When all the academic institutions and community at large are able to recognize academic self-handicapping as a major issue faced by many students, then the rate of negative behavior would reduce and higher percentage of students would be fully engaged with their studies. Hence, the final outcome would be the increasing rate of higher achiever in the institutions and nations, which would also boost the national economy and development and also reduce the percentage of low pay workers and jobless people.

Although academic self-handicapping has been studied by many researchers, none of the previous studies used the reciprocal interaction of emotion, cognition and behavior aspredictors of academic selfhandicapping. Moreover, according to the researchers' knowledge, this is the first self-handicapping study to be conducted within an Islamic higher institution.

\section{The Self-Handicapping Questionnaire (SHQ 2011)}

Self-Handicapping Questionnaire (SHQ 2011), is a modified version of the self-handicapping scale of Rhodewalt (1990), which is a 25 -item Self-Handicapping Scale that measures the maladaptive behavioral dimension where an individual tend to employ excuses and handicaps in relation to their performance. The higher the total score obtained the more an individual tends to use self-handicapping strategies. Rhodewalt (1990) reported a Cronbach alpha of 0.79 in a sample of 503 participants. One month test-retest reliability was 0.74 in 90 participants. In a study conducted by Ross, S. R.; Kelli E. \& Rausch, M. K. (2001), on Self-Handicapping and the Five Factor Model of Personality, Cronbach alpha was 0.76 , indicating an adequate internal 
consistency. The predictive ability of the scale has been confirmed by a number of studies (Rhodewalt, 1994, 1990 and 1986). Our modified SHQ (2011) has been reduced to 20 items where seven items have been restated (Item 5, 6, 8, 12, 16, 18, 19). The scale of SHQ (2011) is between 1 and 7 i.e. from disagreeing very much to agreeing very much.

The reliability of SHQ (2011) was checked during the pilot study with a sample size of 386, and an Alpha reliability of 0.75 was obtained which is within the range of results that were obtained from the previous studies. According to George and Marley, (2003), this result is acceptable.

\section{Student Engagement Questionnaire (SEQ 2011)}

Student Engagement Questionnaire (SEQ 2011) as shown in Appendix B has been adapted from a school engagement scale which was developed from the 3 domains of the school engagement, extracted after the Confirmatory Factor Analysis (CFA) of the student engagement questionnaire. According to Finlay, (2006), the original questionnaire was developed for the intensive sites of USA, by the National Center for School Engagement (NCE, 2006). In a report of a study entitled Quantifying School Engagement, Finlay (2006), explained the process by which NCE (2006) created the school engagement survey as well as the reliability and validity of the instrument. Good result was obtained, whereby all the three constructs were between Cr Alpha 0.79 and 0.92 except for the behavioral engagement at one of the schools (Jacksonville) which was 0.50 . Our instrument adapted all the three scales but with some modifications, by changing negative questions to positive questions. The scale of SEQ (2011) is between 1 and 7 i.e. from disagreeing very much to agreeing very much.

\section{The Present Study}

As a preliminary step to studying the reciprocal relationship between student engagement and academic self-handicapping, the present study had the aim of validating two key instruments on the target non-western population. The two instrruments in question were 1) the Self-Handicapping Questionnaire (SHQ 2011), and 2) the Student 
Engagement Questionnaire (SEQ 2011) which consists of i) the Emotional Engagement Scale, ii) the Behavioral Engagement Scale, and iii) the Cognitive Engagement Scale. We wanted to discover the psychometric properties of these instruments when used on an Asian Muslim population, in a predominantly Muslim setting.

\section{Population and Sampling}

Population and site of this study has been selected based on the present theoretical study which is aiming at studying the predictors of academic self-handicapping behavior among Muslim students. Hence, International Islamic University Malaysia was selected as a site for conducting this study because it is the only Public International Islamic University in Malaysia(where this study was carried-out). IIUM university is having the highest percentage of International students (representing more than 100 countries in the world) when compared to other private International University in Malaysia. Moreover, the researcher gave a priority in studying Muslim students because none of the Islamic Institutions has yet conducted a self-handicapping study. The total population of postgraduate students $(1,114)$ was excluded from the total population of 29,211 IIUM studentsin representing the population of IIUM undergraduate students according to the aims and objectives of this study, hence the study dealt with the total population of 18,097 undergraduates.

In representing the population of undergraduate students of an International Islamic University, a proportionate stratified random sampling was applied. "Stratified sampling is a quantitative sampling procedure in which researchers stratify the population on some specific characteristic (e.g. gender) and then determine the sample group by using the random sampling, from each stratum of the population" (Creswell, $2005 \mathrm{p} 599$ ). It has also been defined as "a process of selecting a sample in the same proportion that they exist in the population" (Gay $2000 \mathrm{p} 126$ ); therefore this study calculated the sample by using gender proportions

The total population of IIUM undergraduates which was obtained from Admission and Record office in October (2011) is 18,097, where 7,272 (40\%) are male students and 10,825 (60\%) are female students (Fig 3.1). Comrey \& Lee (1992) suggested an excellent assumption testing sample size of above 1000 therefore, through the 
proportionate stratified random sampling (Fig 3.1), the researcher study circle II students who were expected to be 1,0355 (575 Males and 780 Females).

\section{Instrumentation}

This study utilizes two types of instruments which include:

Self-Handicapping Questionnaire (SHQ 2011)

Student Engagement Questionnaire (SEQ 2011) consisting of:

Emotional Engagement Scale

Behavioral Engagement Scale

Cognitive Engagement Scale

Both questionnaires applied the Likert scale which range from 1 (disagree very much) to 7 (agree very much) as has been a traditional practice of many researchers who frequently use 5 to 9 point response scales (Schaefer and Presser, 2003). Likewise, Krosnick and Fabrigar (1997) suggested that seven point scales were optimal, and that numerical scale values may be easier to hold in memory than more complex verbal labels therefore, both scales had no wordings in between "disagree very much" and "agree very much". Respondents were free to think and decide where they belong between 1 and 7 . This is also in agreement with various researchers including Saris and Gallhofer (2007), who suggested that not providing a neutral middle category improves both reliability and validity, otherwise information about the real direction which the respondent leans on, might be missed (Converse and Presser, 1986). However, some of the respondents demanded to be told what meant by 2, 3, 4, 5 and 6 , the answer was based on the importance of assessing themselves without the influence of others or anything else.

\section{RESULTS AND DISCUSSION}

\section{Reliability/Internal Consistency of SEQ (2011)}

Assessment for the reliability of SEQ (2011) was done during the pilot study with a sample size of 386 by utilizing SPSS 16, and good result was obtained as indicated in table 1 
Table 1 Reliability of Student's Engagement Questionnaire (2011)

\begin{tabular}{lccc}
\hline Variables & $\begin{array}{c}\text { No of } \\
\text { Items }\end{array}$ & Sample Size & $\begin{array}{c}\text { Alpha } \\
\text { Cronbach }\end{array}$ \\
\hline $\begin{array}{l}\text { Emotional Engagement Vari- } \\
\text { ables }\end{array}$ & 14 & 386 & 0.87 \\
$\begin{array}{l}\text { Behavioral Engagement Vari- } \\
\text { ables }\end{array}$ & 14 & 386 & 0.80 \\
Cognitive Engagement Variables & 16 & 386 & 0.84 \\
\hline
\end{tabular}

All three scales which form the SEQ (2011) maintained good Cr. Alpha of between 0.87 and 0.80 therefore, we consider our instrument as a good instrument as also recommended by many researchers including George \& Marley (2003), who highlighted a common rule of thumb for describing internal consistency as: Cr Alpha $\geq 0.9=$ excellent; $\geq 0.8=$ good; $\geq 0.7=$ acceptable; $\geq 0.6=$ questionable $; \geq 0.5=$ poor; and $<0.5$ unacceptable.

Fifteen students were also interviewed in three different Focus Group Interview sessions. Four brothers were involved in the first focus group interview; the second group consisted of six sisters; while the third group consisted of three sisters. The responses of all the interviewees indicated the existence of self-handicapping behavior among the IIUM undergraduate students especially the Halaqah students. Hence, the responses obtained were adequate for verification.

According to the agreement between the researcher and the assistant director of CCAC (2011), 1,032 questionnaires were issued to 31 chief facilitators of Halaqah II students. But, only 990 questionnaires were handed over to chief facilitators who were present during the facilitators' meeting with the assistant director of the CCAC on 24th Sept. 2011. The rest of the questionnaires were collected from the office by the chief facilitators as instructed by the assistant director of the CCAC and the researcher. Chief facilitators (CF) were instructed to conduct the survey to all their students and then collect the questionnaires and deliver them either to the assistant director of CCAC or to the researcher and the researcher finally collected all the filled-in questionnaires for analysis. A total number of 882 questionnaires were returned within the period of three months. Data from the first 386 respondents was utilized in 
assessing the reliability of the two questionnaires which were applied in this study. The results are indicated in table 3.2.

\section{MODEL SPECIFICATION}

According to the underlying theories, the researcher drew the theoretical model of POASH which forms the baseline of this study thus, four basic individual constructs were specified (Table 2) and drawn (see Figures 1, 2, 3 \& 4) accordingly.

Table 2 Specifications of the five construct of the POASH Model

\begin{tabular}{lc}
\hline FOUR MEASUREMENT SCALES & TOTAL ITEMS \\
OF POASH & \\
\hline Emotional Engagement & 14 \\
Behavioral Engagement & 14 \\
Cognitive Engagement & 16 \\
Self-handicapping Behavior & 20 \\
\hline TOTAL & 64
\end{tabular}

\section{TEST OF CRITICAL ASSUMPTIONS IN FACTOR ANALYSIS}

Prior to performing Confirmatory Factor Analysis, the suitability of data for factor analysis was assessed. Principal Component Analysis was carried out during the pilot study with the aim of defining the underlying dimensions of the collected data in the pilot study. 
Individual Specification of the four factors of the POASH Model

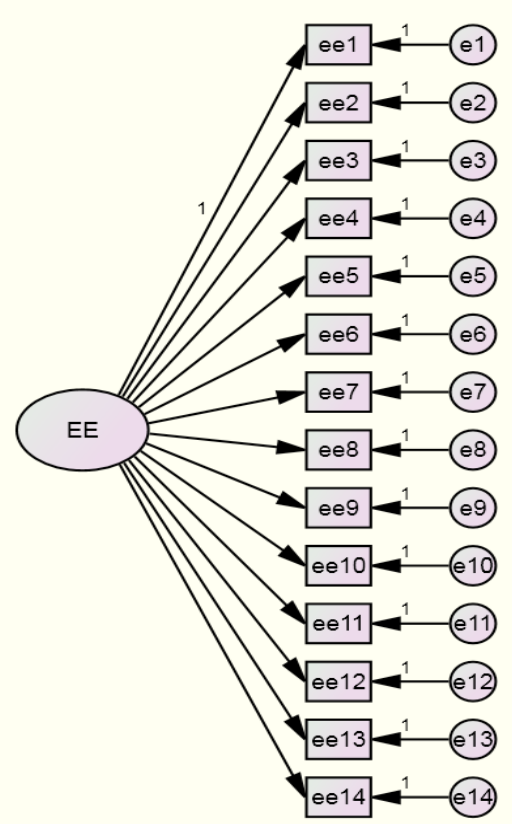

Figure 1: Emotional Engagement Construct 


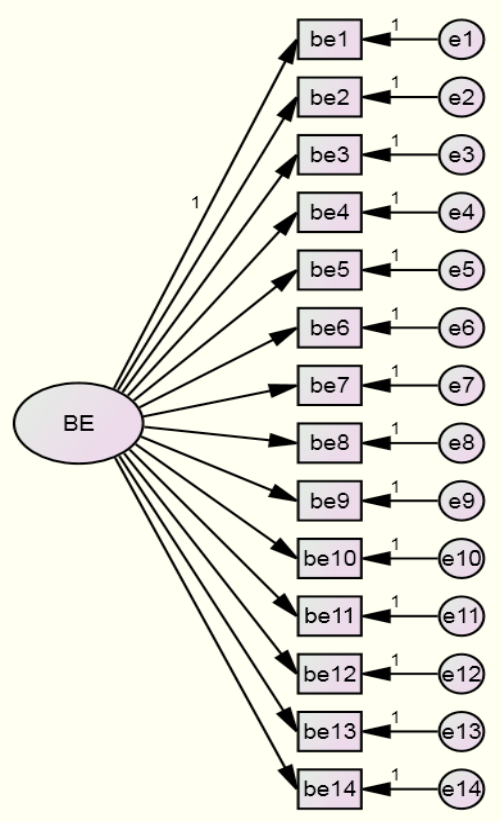

Figure 2 : Behavioral Engagement Construct 


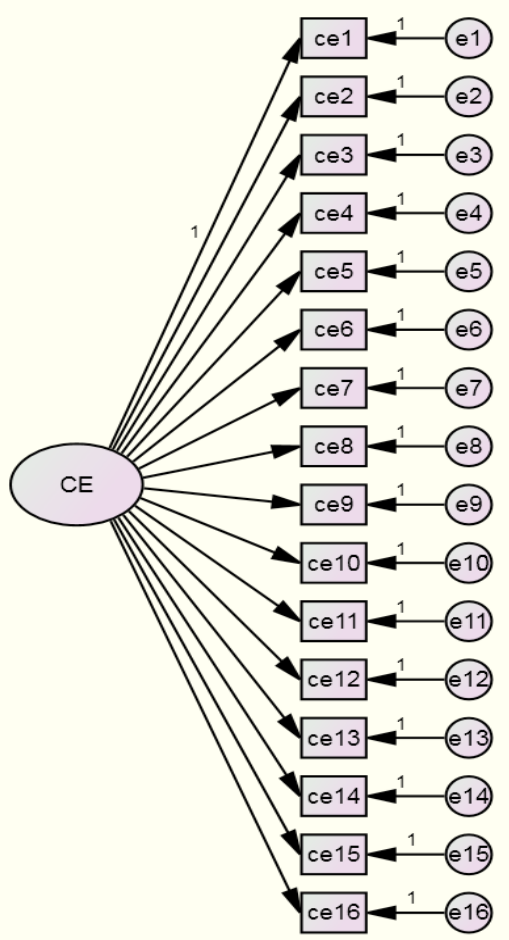

Figure 3: Cognitive Engagement Construct 


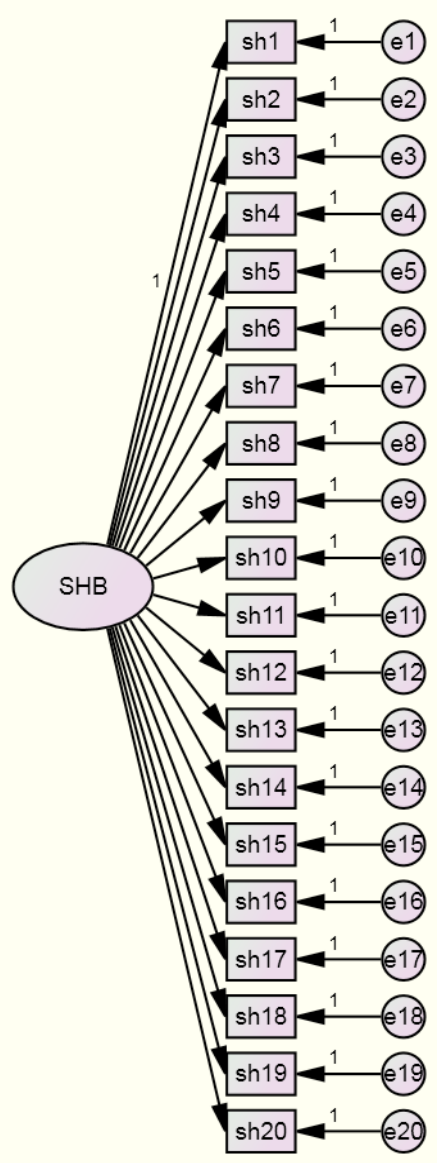

Figure 4 : Self-Handicapping Behavior Construct

\section{Results of the Bartlett's test of Sphericity}

The test of critical assumptions in factor analysis was carried out whereby the result of Kaiser-Meyer-Olkin and Measure of sampling 
adequacy culculatedduring the pilot study with a total sample size of $(\mathrm{N}=790)$ for all the three scales of student engagement were more than 0.8 and the SHB was 0.78 (Table 3).

Table 3 KMO and Bartlett's Test of the 4 scales of POASH

\begin{tabular}{lcccc}
\hline Scales of use model & KMO & Chi-square & $D f$ & $\begin{array}{c}\text { Signifi- } \\
\text { cance }\end{array}$ \\
\hline Emotional Engagement & .89 & 4.44 & 91 & .000 \\
Behavioral Engagement & .82 & 2.99 & 91 & .000 \\
Cognitive Engagement & .86 & 3.92 & 120 & .000 \\
Self-handicapping Behav- & .78 & 1.75 & 171 & .000 \\
ior & & & & \\
\hline
\end{tabular}

Because all the four scales of POASH are beyond the normal $\mathrm{KMO}$ which is $\geq 0.6$ therefore, $\mathrm{KMO}$ results indicate an adequate measure of all the four scales. This is also supported by the results of Bartlett-Sphericity test which revealed that all four scales of POASH model are statistically significant with p-values of 0.000 , whereby significant Bartlett's Tests of Sphericity is $\leq 0.05$ (Pallant, 2005, p.182) and $\chi^{2}$ of between 1.75 to 4.44 , whichsuggests that Factor analysis is appropriate and that the sample size is adequate for meaningful factorability (Pett, Lackey, and Sulivan, 2003).

\section{COMPONENT MATRIX RESULTS OF THE THREE}

\section{SCALES OF SEQ (2011)}

Table 4 Emotional Engage. Component Matrix

\begin{tabular}{cccc}
\hline & \multicolumn{3}{c}{ Component } \\
& 1 & 2 & 3 \\
\hline ee1 & .511 & .662 & \\
ee2 & .549 & .654 & \\
ee3 & .519 & .620 & \\
ee4 & .611 & & \\
ee5 & .697 & &
\end{tabular}




\begin{tabular}{ccc} 
ee6 & .740 & \\
ee7 & .589 & \\
ee8 & .707 & -.492 \\
ee9 & .563 & .508 \\
ee10 & .516 & \\
ee11 & .724 & \\
ee12 & .719 & \\
ee13 & .688 & \\
ee14 & .621 & \\
\hline
\end{tabular}

PCA 3 Components Extracted

Table 5 Behaviour Engagement Component Matrix

\begin{tabular}{|ccccc}
\hline & \multicolumn{4}{c}{ Components } \\
\hline be3 & 1 & 2 & 3 & 4 \\
be6 & .739 & & & \\
be14 & .676 & -.431 & & \\
be5 & .668 & & & \\
be2 & .642 & -.556 & & \\
be4 & .597 & & & \\
be10 & .569 & & & \\
be9 & .552 & & -.420 & \\
be8 & .548 & & & \\
be11 & .545 & & & \\
be12 & .510 & & & \\
be13 & .458 & .600 & & \\
be7 & .467 & .595 & & \\
\hline be1 & .459 & & & \\
\hline
\end{tabular}

PCA: 4 components extracted 
Table 6 Cognitive engagement Component Matrix

\begin{tabular}{ccccc}
\hline & \multicolumn{4}{c}{ Component } \\
& 1 & 2 & 3 & 4 \\
\hline ce5 & .673 & & & \\
ce15 & .656 & & & \\
ce3 & .638 & -.443 & & -.459 \\
ce9 & .605 & & & \\
ce8 & .600 & & & \\
ce4 & .597 & -.516 & & \\
ce12 & .586 & .507 & & \\
ce14 & .578 & & -.573 & \\
ce6 & .528 & -.435 & & \\
ce2 & .503 & -.473 & & \\
ce1 & .501 & -.409 & & \\
ce16 & .498 & & & \\
ce11 & .492 & .438 & & \\
ce7 & .444 & & & \\
ce10 & .468 & .494 & & \\
ce13 & .556 & & -.586 & \\
\hline
\end{tabular}

PCA: 4 Component extracted

Principal Component analysis of all the four scales in our study was carried out in order to select items for Confirmatory Factor Analysis through Structural Equation Modelling. Items were determined from the results of Component Matrix. According to the results of component matrix (Tables: $4-6$ ), all three scales of student engagement consist of more than two components however, Items in components No: 2-4 of all the three scales are cross loading (highlighted in green colour) with other factors. Almost all items which are not cross loading belong to the first component of all the three scales and are highlighted in yellow colour.

Thus, all three scales were fixed at one factor extraction and all the 44 items of student engagement scale were analysed using the Varimax rotation where the factor loadings of less than 0.4 were deleted. Tables 
7 to 9 highlights retained and deleted items from the three scales of student engagement.

\section{ITEM LOADINGS OF THE RETAINED ITEMS OF THREE FACTORS OF STUDENT ENGAGEMENT}

\begin{tabular}{|c|c|c|}
\hline ITEM & EMOTIONAL ENGAGEMENT SCALE & Loadings \\
\hline EE6 & I like most of my Lecturers at the university. & .740 \\
\hline EE11 & Most of my lecturers understand me. & .724 \\
\hline EE12 & I feel excited by the academic work at the university. & .719 \\
\hline EE8 & Most of my lecturers care about how I'm doing. & .707 \\
\hline EE5 & The Lecturers at my university treat students fairly. & .697 \\
\hline EE13 & My lecture room is a fun place to be. & .688 \\
\hline EE14 & $\begin{array}{l}\text { I feel I can go to my lecturers with the things that I need } \\
\text { to talk about. }\end{array}$ & .621 \\
\hline EE4 & I am happy to be at my university & .611 \\
\hline EE7 & The discipline at my university is fair. & .589 \\
\hline EE9 & Most of my lecturers know the subject matter well. & .563 \\
\hline EE2 & $\begin{array}{l}\text { When I first walked into my university I thought it was } \\
\text { Friendly }\end{array}$ & .549 \\
\hline EE3 & $\begin{array}{l}\text { When I first walked into my university I thought it } \\
\text { was Clean }\end{array}$ & .519 \\
\hline EE10 & $\begin{array}{l}\text { There is an adult at University that I can talk to, about } \\
\text { my problems. }\end{array}$ & .516 \\
\hline EE1 & $\begin{array}{l}\text { When I first walked into my university I thought it } \\
\text { was Good }\end{array}$ & .511 \\
\hline
\end{tabular}

Note: The alpha reliability $=.87$

The results indicate emotional and cognitive scales maintained all their items but, behaviour engagement scale lost one of its item i.e. BE 7 = I stay at home after the lecture hours. However, the researcher restricted all three scales into single components due to statistical as well theoretical reasons. 
Table 8 Behavioural Engagement Scale

\begin{tabular}{llc}
\hline ITEM & \multicolumn{1}{c}{ BEHAVIORAL ENGAGEMENT SCALE } & Loadings \\
\hline BE3 & I always follow the university rules & .739 \\
BE6 & $\begin{array}{l}\text { I am never absent at the university without a genuine } \\
\text { reason }\end{array}$ & .676 \\
BE14 & I always obey university dress code & .668 \\
BE5 & I never skip classes & .642 \\
BE2 & I work very hard when I am in the lecture room & .597 \\
BE4 & I never get in trouble at the university & .569 \\
BE10 & I regard all my colleagues equally no matter which & .552 \\
& country they came from & \\
BE9 & I respect most of my lecturers. & .548 \\
BE8 & I enjoy the work I do in class & .545 \\
BE11 & I always avoid gossiping & .510 \\
BE13 & I hate to see two people fighting & .467 \\
BE1 & I never thought of dropping out of the university & .459 \\
BE12 & I try to avoid arguments & .458 \\
\hline BE7 & I stay at home after the lecture hours (Deleted) & Deleted \\
\hline
\end{tabular}

Note: The alpha reliability $=.83$

Table 9 Cognitive Engagement Scale

ITEM COGNITIVE ENGAGEMENT SCALE

Item

Loading

CE5 I am getting a good education at my university $\quad .673$

CE15 I try my best at the university.

CE3 What I learn in the university is very important for my $\quad .638$ future life

CE9 When I read a book, I ask myself questions to make $\quad 605$ sure I understand what it is about.

CE8 Most of my courses are very interesting $\quad 600$

CE4 What I learn in the university is very important in get- $\quad .597$ ting a good job or career after completion of my studies 
CE12 I check my schoolwork for mistakes

CE14 If I don't understand what I read, I go back and read it $\quad .578$ over again.

CE13 If I don't know what a word means when I am reading, I do something to figure it out, like look it up in the dictionary or ask someone.

CE6 My aim is to graduate from the university

CE2 It is very important to get good CGPA

CE1 I think education is very important

CE11 I talk with people outside of school about what I am learning in class

CE10 I study at home even when I don't have exam.

.468

CE7 My next aim is to do Masters course

.444

Note: The alpha reliability $=.84$

In summary, the results of component factor analysis of the three scales of student engagement questionnaire indicated all three scales consist of more than two constructs, but most of the items are cross loading with majority of good items existing in the first components. Therefore, due to predetermined theoretical aspects and the statistical findings, all three scales of SEQ were fixed at one factor extraction. Almost all 44 items of SEQ were retained except one (b7) from the behavioral engagement scale which was bellow 0.4 and therefore deleted during the extraction. All other (43) items were retained for further analysis. 


\section{Component Matrix of SHQ (2011)}

Table 10 Component Matrix ${ }^{a}$ - Self-handicapping Behaviour

\begin{tabular}{cccccc}
\multicolumn{5}{c}{ Component } \\
\hline sh5 & 1 & 2 & 3 & 4 & 5 \\
sh6 & .426 & .651 & & & \\
sh7 & .530 & .524 & & -.501 & \\
sh8 & .533 & & & -.489 & \\
sh9 & .486 & & & \\
sh10 & & -.402 & & -.467 \\
sh11 & & & & \\
sh12 & & & & \\
sh13 & .468 & -.493 & & & \\
sh14 & .462 & & & \\
sh15 & .479 & & & & \\
sh17 & .431 & & & & \\
sh18 & & & & & \\
sh19 & & & & \\
sh20 & .594 & & &
\end{tabular}

Component matrix of self-handicapping questionnaire (Table 10) shows that self-handicapping behaviour scale consists of five constructs but most of the items from component two to five do cross-load (highlighted in green colour) with other indicators with the exception of two good $(\geq 0.4)$ items in the second component and single good items in fourth and fifth components however, majority of good items (highlighted in yellow colour) are in the first component therefore SHB scale is also considered to be a single component scale.

Moreover, self-handicapping behavior was pre-determined to be a single factor according to the theoretical framework, previous studies and results of descriptive statistics therefore, SHQ was also fixed at one factor extraction and all the 20 items of SHQ were analysed using the Varimax rotation where the factor loading of less than 0.4 were deleted (Tables: 11). Thus after the removal of the cross-loading items and factor loadings of $<0.4$ only fifteen items out of twenty items of self-handicapping behaviour scale were retained for further analysis. 


\section{Deleted items from SHQ (2011) are:}

SH1: When I do something wrong, my first impulse is to blame circumstances.

SH2: I tend to put things off until the last moment.

SH3: I tend to over-prepare when I have an exam or any kind of performance.

SH4: I suppose I feel "under the weather" more often than most people

SH16: I do not mind taking a drug that interferes with my ability to think clearly and do the right thing.

Table 12 Short Self-Handicapping Scale (15)

\begin{tabular}{|c|c|c|}
\hline ITEM & SELF-HANDICAPPING SCALE & $\begin{array}{c}\text { Item } \\
\text { Loading }\end{array}$ \\
\hline 14 & $\begin{array}{l}\text { I admit that I am tempted to rationalize when I don't } \\
\text { live up to other's expectations }\end{array}$ & .707 \\
\hline 13 & $\begin{array}{l}\text { I would do much better if I did not let my emotions get } \\
\text { in the way }\end{array}$ & .650 \\
\hline 10 & $\begin{array}{l}\text { I would rather be respected for doing my best than } \\
\text { admired for my potential. }\end{array}$ & .624 \\
\hline 11 & $\begin{array}{l}\text { I prefer small pleasures in the present, to larger plea- } \\
\text { sures in the dim future. }\end{array}$ & .541 \\
\hline 7 & $\begin{array}{l}\text { I tend to get very anxious before an exam or perfor- } \\
\text { mance. }\end{array}$ & .753 \\
\hline 8 & $\begin{array}{l}\text { I am easily distracted by noises or my own creative } \\
\text { thoughts when I try to read. }\end{array}$ & .697 \\
\hline 20 & $\begin{array}{c}\text { Sometimes I get so depressed that even easy tasks } \\
\text { become difficult. }\end{array}$ & .590 \\
\hline 12 & $\begin{array}{l}\text { I sometimes enjoy being mildly ill for a day or two, } \\
\text { because it takes off the pressure. }\end{array}$ & .735 \\
\hline 9 & $\begin{array}{l}\text { I try not to get too intensely involved in competitive } \\
\text { activities so it won't hurt too much if I lose or if I do } \\
\text { poorly. }\end{array}$ & .583 \\
\hline 15 & $\begin{array}{l}\text { I often think I have more than my share of bad luck in } \\
\text { sports, card games, and other measures of talent. }\end{array}$ & .518 \\
\hline
\end{tabular}


6 I do not make proper preparation before I sign up for a course or engage in any important activity

19 I can let emotional problems in one part of my life interfere with other things in my life.

17 I overindulge in food and drink more often than I should.

18 When something important is coming up, like an exam or a job interview, I do not mind sleeping late the night before Note: The alpha reliability $=.7$

In summary, results of component factor analysis of selfhandicapping behavior scale as indicated in the component matrix results, show several items which are cross loading and also bellow 0.4 , with majority of good items in the first component. Therefore due to predetermined theoretical aspects and the statistical findings, the SHQ was fixed at one factor extraction.Five items were removed during PCA due to cross-loading and factor loadings of $<0.4$ therefore; only fifteen items were retained for further analysis.

\section{DATA ANALYSIS PROCEDURE}

Data analysis procedure of the present study involves two phases, the first phase deals with the initial analysis and the second phase deals with the analysis of the main study. The initial stage involves: data preparation, descriptive analysis and reliability analysis. While main study involves: single groups using two step analysis to develop the first and second order models of university student engagement; Multigroup analysis begins with the formulation of the baseline models, followed by simultaneous analysis between the two gender groups and between the two nationality status groups while simultaneously assessing the interactions between the variables before constraining the models. Lastly the models were constrained but with very little difference between the constrained and unconstrained models

\section{Statistical analysis of the items}

The researcher estimated the model specifications and checked the normality assumptions as well as outliers during the pilot study and also 
during the main study. In so doing, the researcher checked the means, standard deviation, the skewness and kurtosis which comprehend the $Z$ score: skewness -3 to +3 , kurtosis -10 to +10 and critical ratio of multivariate coefficient \pm 2.58 (Kline, 2011). Outliers were identified by using Mahalanobis distance and removal of cases with both $\mathrm{p} 1 \&$ p2 at Mahalanobis distance of 0.000 was executed. The researcher computed internal consistency/reliability estimates (Cronbach's Alpha) of all the four scales, firstly during the pilot study and secondly during the main study. Both results indicated reliable results of Cronbach Alpha for both instruments i.e. student engagement questionnaire and self-handicapping questionnaire.

\section{DISCUSSION}

The results substantiated the psychometric adequacy of the measure of student engagement model as well as the psychometric adequacy of the measure of the structural model of predictors of academic selfhandicapping behavior. Both Measures seemed to be sufficient to represent the measurement tools of assessing student engagement and student's academic self-handicapping behavior.

The results validated the good fit of the model of predictors of academic self-handicapping behavior (POASH). This result supports the basic assumption of Relative Emotive Behavior Therapy which posits that cognitions, emotions, and behaviors interact significantly and have a reciprocal cause and effect relationship (Corey, 2013 \& 2006). In addition the results are congruent with the results of Ellis, 2001a, 2001b, 2002, 2011; Ellis \& Dryden, 2007; Wolfe, 2007) which also found the significant relationship of emotion, cognition and behavior. However, the current study axtended this theory by proving that the reciprocal interaction of emotion, behavior and cognition significantly and negatively influence self-handicapping behavior.

Interactions of effects between the variables were revealedand results show a direct significant negative influence of student engagement on self-handicapping behavior and indirect negative influence of emotion, 
behavior and cognition via student engagement on self-handicapping behavior.

Gender invariance indicates that the variability of females' behavior engagement explains the highest $(77 \%)$ followed by that of male students (68\%). This is supported by few studies which reported that women self-handicap more than men for example Elliot and Church (2003); and Rhodewalt (1997). However, this finding is contrary to most of the previous findings which directly compared behavioral self-handicap (disengagement or withdrawal practice) and discovered that males practice more behavioral self-handicap than women for example Lucas and Lovalgia (2005), Hirt Deppe \& Gordon (1991); Rhodewalt and Davison, 1986; Harris and Snyder, 1986; Berglas and Jones, 1978). Furthermore, Arkin and Oleson (1998) and Rhodewalt and Davison (1986), commented that, repeatedly researchers discover a gender difference whereby men self-handicap more than women. In addition, Rhodewalt (1990) reported that this difference is one of the most consistent findings in self-happing literature.

According to male students' emotional engagement variance predictions are almost the same between male (54\%) and female (51\%). This tallies with other previous studies on claimed self-handicap (reported stressed), whereby they reported both male and female selfhandicap alike (Rhodewalt, 1990; and Jones \& Rhodewalt, 1982). Lastly, this result indicated cognitive engagement to be predicting the lowest in both male and female students, whereby male students' cognitive variance predicted self-handicapping higher $(48 \%)$ in comparison to female students' cognitive variance (22\%), meaning that female students are more willing to go beyond the basic requirements to master the difficult skills than male students.

.The model of nationality status invariance indicates that the responses of national students explains self-handicap more than the responses of international students where $25 \%$ variance of student engagement explains self handicapping behavior of local students, while a lower percentage of only $12 \%$ of international students' engagement explains self handicapping behavior of international students. This finding is explained by Status characteristic theory of Berger, Cohen, and Zelditch (1996), which states that members of a group form expectations about each other's competence to contribute to group goals based on 
their status characteristics. Possibly being away from their home countries the international students engage with their study more than the nationals in order to finish earlier and return to their home countries. In addition, Podolny (1993) explained that individuals expected to contribute more are more highly valued by the group, held in higher esteem. Since local students tend to be more highly valued and esteemed than international students therefore, there is a higher possibility that national students self-handicap more than internal students in order to protect expectations for personal competence. Furthermore, Pulford, Johnson and Awaida, (2005) argued that self-handicapping behavior is influenced by cultural differences because the underlying reasons for self-handicapping differed between different countries. .

However, International students' behavior engagement and national students' behavior are almost the same i.e. $69 \%$ of behavior engagement of international undergraduates explains self-handicapping while $68 \%$ of behavior engagement of nationals' explains their self-handicapping. This is probably due to the same characteristics of young adults no matter which nationality they belong to, this is supported by Jeffrey (2007) who reported that:

One claim made frequently about emerging adults is that they are miserable lot, wracked with anxiety \& unhappiness, intimidated to the point of paralysis about the grim prospects for entering the adult world. According to this view, the years from age 18 to 25 are dark and dreary period of life course. Emerging adults are typically confused and glum and overwhelmed by what the world seems to require from them.

Results indicate that emotional engagement of international students explains $68 \%$ of self-handicapping while only $54 \%$ emotional engagement of national students explains their self-handicapping. Possibly the international students have a lower relationship with lecturers, colleagues, faculty, university due to the adjustment period which they are going through. Some of the students take a longer time to adjust with the new country, new university, new rules and regulations, new lectures, new class-mates, new culture and other issues. These situations lead them into having a low self-esteem which Newman and Wadas (1997) reported that the use of self-handicaps between persons with stable versus unstable self-esteem are much stronger than between persons with generally high versus low self-esteem. 
Variance of cognitive engagement of national students $40 \%$ has a very small difference with that of international students' which is $38 \%$. The low percentages and the small differences between them might be due to low self-esteem which mostly occursduring the early adjustment period for both international and national students with international student having a higher percentage due to longer period of adjustment than the local students.

\section{Conclusion and Recommendations}

In enhancing student engagement and discouraging academic selfhandicapping, recommendations shall be given to counselors, psychologists, lecturers, and student counselors in applying structured observation analysis in order to identify individual self-handicappers and deal with them individually by using cognitive behavior therapy. Suggestions shall be given to facilitators of Islamic studies to apply Zimmerman's self-regulated learning skills which consist of goal setting and planning, self-monitoring, self-evaluating, organizing, transforming, rehearsing and memorizing. Lastly, Whole Brain Teaching has been recommended in order to help the low esteemed students.

\section{BIBLIOGRAPHY}

Anderson, J.C. and Gerbing, D.W. (1982). Some methods for re-specifying measurement models to obtain unidimensional construct measurement Journal of Marketing Research, 19, 453-460

Bandura, A. (1986).Social foundations of thought and action: a social cognitive theory. Englewood Cliffs, NJ: Prentice Hall. 617

Berger, J.B., Cohen, P. and Zelditch, M (1972).status characteristics and social interaction.American Sociological Review 37:241-56.

Berglas, S. and Jones, E.E (1978). Drug Choice as Self-Handicapping Strategy in response to noncomitant success.Journal of Personality \& Social Psychology, 36, 405-417

Blyth, D. A., Simmons, R. G., \& Carlton-Ford, S. (1993).The adjustment of early adolescents to school transitions Journal of Early Adolescence, 3(12), 105- 120. 
Byrne, B.M. (2010).Structural Equation Modeling with AMOS: Basic Concepts, Applications and Programming(2nd Edn.). Routledge Taylor \& Francis group. New York, USA pp5, 53-160

CAS (Council for the Advancement of Standards in Higher Education) (1999). the role of counseling programs: CAS standards contextual statement. Washington, DC: CAS.

Chung, H.H., Elias, M., and Schneider, K (1998).Patterns of individual adjustment changes during middle school transition.Journal of School Psychology, 36(1), 83-101

Co-Curricular Activity Center (2011).Study circle guide book. International Islamic University Malaysia KL, Malaysia pp9-15, 83-100

Comrey, A.L. \& Lee, H.B. (1992).A first Course on Factor Analysis (2nd Edn.). In: Raise, S.P., Waller, N., \& Comrey, A.L. (2000). Factor Analysis and Scale Revision Psychological Assessment Vol. 12, No. 3, 287-297

Converse, J.M. and Presser, S. (1986).Survey questions: handcrafting the standardized questionnaire, Newbury Park CA: Sage Publication.

Corey, G (1996).Theories and Practice of Counseling and psychotherapy(5th Ed.)Brooks/Cole Publishing Company CA USA pp134-135 \& pp317-357

Corey, G. (2013). Theory and Practice of Counseling Therapy(9th Ed.) Brooks/ Cole Publishing Company 263-300

Counsel for the Advancement of Standards in Higher Education (CAS) (1999). The role of counseling programs:CAS standards contextual statement. Washington, DC: CAS

Covington, M.V. (1992).Making the grade: a self-worth perspective on motivation and school reform Cambridge: Cambridge University Press

Creswell, J.W (2005). Educational research planning, conducting, and evaluating quantitative and qualitative research Pearson Education, Inc New Jersey, USApp354; 509-515

Eccles, J. S., Wigfield, A., Flanagan, C.A., Miller, C., Reuman, D.A., \& Yee, D. (1989). Self-concepts domain values, and self-esteem: Relations and changes at early adolescence. Journal of Personality 57, 283-310

Eccles, J. S., Wigfield, A., Midgley, C., Reuman, D., MacIver, D., and Feldlaufer, H (1993b). Negative effects of traditional middle schools on students' motivation The Elementary School Journal 93 (5) $553-574$ 
Elliot, A.J., and Church, M.A. (2003). A motivational analysis of defensive pessimism and self-handicapping Journal of Personality, 71, 369-396

Ellis, A \& Dryden, W. (2007).The practice of rationale behavior therapy (2nd Ed) New York Springer

Ellis, A. (1993) In Corey, G. (1996). Theory and Practice of Counseling Therapy(5th Ed.). Brooks/Cole Publishing Company 317-359

Ellis, A. (2001a). Feeling better, getting better, and staying better, Atascadero, CA: Impact

Ellis, A. (2001b).Overcoming destructive beliefs, feelings, and behaviors Amherst, NY: Prometheus Books

Ellis, A. (2002).Overcoming resistance: A rational emotive behavior therapy integrated approach (2nd Ed.). New York Springer

Ellis, A. (2011). Rational emotive behavioral therapy In R. Corsini \& D. Wedding (Ed.) Current Psychotherapy Washington, D.C: USA

Epstein, J.L. \& McPartland, J.M. (1976).the concept and measurement of school life American Educational Research 13 15-30

Finlay, K.A. (2006).Quantifying School Engagement: Research Report. National Center for School Engagement c/o Colorado Foundation for Families and Children, Denver USA

Fuertes, J.N. \& Gretchen, D. (2001).Emerging theories of multicultural counseling in Handbook of Multicultural Counseling by Ponteretto J.G, Casas, J.M., Subuki, $\quad$ L.A \& Alexander, C.M. (pp. 509541), Thousand Oaks: Sage Publications.

George, D., \& Mallery, P. (2003).SPSS for Windows step by step: A simple guide and reference11.0update (4th Ed.) Boston: Ally \& Bacon. 231

Harris, R.N. and Snyder, C.R. (1986). The role of uncertain self-esteem in self-handicapping Journal of Personality and Social Psychology, 51, 451458

Harter, S. (1981). A new self-reported scale intrinsic versus extrinsic orientation in the class-room: motivation \& informational components Developmental Psychology 17, 300-312

Higgins, R.L. and Hariss, R.N. (1988). Strategic 'alcohol' use: drinking to self-handicap Journal of Social and Clinical Psychology, 6, 191-202

Hirsch, B. \& Rapkin,.B (1987). The transition to junior high school: A longitudinal study of self-esteem psychological symptomology, school life and social support value 
Hirt, E.R. Deppe, R.K., and Gordon, L.J. (1991).Self-Reported Versus Behavioral Self Handicapping: Empirical Evidence for a Theoretical Distinction.Journal of Personality and Social Psychology, 61(6), 981-991

Jones, E.E. and Berglas, S. (1978). Control of attributions about the self through self- handicapping strategies: The appeal of alcohol and role of underachievement. Personality and Social Psychology Bulletin, 4, 200206

Jones, E.E. and Rhodewalt, F. (1982).The Self-Handicapping Scale. Unpublished manuscript

Jones,

S.L. \&

Butman,

R.E.

(1991).

Modern Psychotherapies:AComprehensive Christian Appraisal.

Downers Grove, IL: Intervarsity Press. p145

Jöreskorg, K.G. and Sörbom, D. (1984).LISREL V1: Analysis of linear structural relationships by the method of maximum likelihood. Chicago: National Educational Resources

Krosnick, J.A, and Fabriger, L.R (1997).Designing Rating Scaling for effective Measurement in surveys: initial evidence.New directions for evaluation, $70, \quad 29-43$

Lucas, J.W. \& Lovaglia, M.J. (2005).Self-Handicapping: Gender, Race, and Status. Current Research in Social Psychology Vol.10 No.15

MacCallum, R.C \& Austin, J.T. (2000).Application of structural equation modeling in psychological research.Annual Review of Psychology, 51, 201-226

MacCallum, R.C. (1995). Model specification: Procedures, strategies and related issues Instructure equation modeling: Concepts, Issues and applications, R.H. Hoyle (Ed.). Thousand Oaks: Sage Publications, Inc., pp16-29

MacIver, D.J. \& Epstein, J.L (1993). Middle grades research: Not yet mature no longer a child. The Elementary School Journal 93(5), 519-534

Marsh (1989). Age and sex effects in multiple dimensions of self concept preadolescents to early adulthood Journal of Educational Psychology 81417 430

Martin, A.J., Marsh, H.W., and Debus, R.L. (1999). Self-Worth Motivation Theory and Need Achievement Theory: A Quadripolar Representation of Self- handicapping and Defensive Pessimism, University of Sydney, Australia 
McCrea, S.M., Hirt, E.R. and Milner, B.J. (2008). she works hard for the money valuing effort underlies gender differences in behavioural self-handicapping. Journal of Experimental Social Psychology, 44, 292-311

Midgley, C., \& Urdan, T. (2001). Academic self-handicapping and performance goals: A further examination. Contemporary Educational Psychology, 26, 61-75.

Midgley, C., Kaplan, A., Middleton, M., Maehr, M.L., Urdan, T., Anderman, L.H., et al. (1998). The development and validation of scales assessing students' achievement goal orientations Contemporary Educational Psychology, 23, 113-131

National Center for School Engagement (2006).quantifying School Engagement: $\quad$ Research Report. Promoting attendance, attachment and achievement Colorado foundations for Families and Children, USA

Newman, F.M. (1992).Student engagement and achievement in American Schools. www.getcited.org/pub/102987053

Norem, J.K. and Cantor, (1986). Anticipating and post hoc cushioning strategies: Optimism and defensive pessimism in 'risky' situations Cognitive Therapy Research 10, 347-362

Nurius, P.S. and Cormier, S. (2003).Interviewing and change strategies for helpers: Fundamental Skills and Cognitive Behavioral Interventions(5th Ed.) Thomson Brooks/Cole, Australia p255

Pederson, P.B. (2007). Ethics, Competence and Professional issues in CrossCultural Counseling 01-Pederson.qxd

Pulford, B.D., Johnson, A., and Awaida,M. (2005). A cross-cultural study of predictors of self-handicapping in university students Personality and Individual Differences 39, 727-737

Rhodewalt, F. \& Vohs, K.D. (2005).Defensive strategies, motivation and the self, in A Elliot \& Dweck (Ed.) Handbook of competence and motivation (pp 548-565) New York: Guilford Press.

Rhodewalt, F. (1990). Self-Handicappers: Individual Differences in the Preference for anticipatory, Self-Protective acts. Pp. 69106 in Self-Handicapping: The Paradox that Isn't. Edited by Raymond, Higgins, C.R., Snyder and Berglas, S. New York: Plenum. 
Rhodewalt, F. (1994). Conceptions of ability, achievement goals, and individual differences in self-handicapping behavior: On the application of implicit theories. J. Person. 62: 67-85.

Rhodewalt, F. and Fairfield, M. (1991).claimed self-handicaps and the self-handicapper: on the relation of reductions in intended effort to performance Journal of Personality and Social Psychology, 25, 402-417

Rhodewalt, F., \& Davison, J. (1986). Self-handicapping and subsequent performance: Role of outcome valance and attribution certainty. Basicand Applied Social Psychology, 7, 307-322.

Rhodewalt, F., Morf, C., Hazlett, S. and Fairfield (1991).self-handicapping: the role of discounting and augmentation in the preservation of selfesteem Journal of Personality and Social Psychology 61, 121-131

Sahranç, U. (2011). An investigation of the relationships between selfhandicapping \& depression, anxiety and stress International Online Journal of Educational Sciences 3(2), 526-540

Saris, W.E. and Gallhofer, I.N. (2007).Design, evaluation and analysis of questionnaires for survey research Hoboken, NJ: John Wiley.

Seligman, M.E.P., Nolen-Hoeksema., S., Thornton, N., Thornton, K.M. (1990). Explanatory Style as a Mechanism of Disappointing Athletic Performance Psychological Science 1(2): 143-146.

Shepperd, J.A. \& Arkin, R.M. (1989). Determinants of self-handicapping: Task importance and the effects of pre-existing handicaps on selfgenerated handicaps Personality and Social PsychologyBulletin15, $101-112$

Simons, R.G. \& Blyth, D.A. (1987).Moving into adolescence: The impact of pubertal change and school context Hawthorn, Aldine De Gruyler

Sue, D.W. \& Sue, D. (2003). 4th Ed. Counseling the culturally diverse: Theory and practice. New York: John Wiley and sons

Tice, D. M. (1991). Esteem protection or enhancement? Self-handicapping motives and attributions differ by trait self-esteem. J. Person. Soc. Psychol. 60: 711- 725

Urdan, T (2004). Using multiple methods to assess students' perceptions of classroom goal structures European Psychologist, 9(4), 222-231

Wayne, Drevets, Marcus, and Raichle (1998). Reciprocal Cerebral Blood Flow during Emotional versus Higher Cognitive ProcessesCognitive and Emotion Vol.12, Issue No.3, pp 353-385 
Weiner, B. (1994). Integrating social and personal theories of achievement striving. Review ofEducational Research, 64(4), 557-573

Wigfield, A. Eccles, J.S. MacIver, D. Reuman, D.A. \& Midgley (1991). Transitions during early adolescence: Changes in children's domainspecific self- perceptions and general self-esteem across the transition to junior high school. Developmental Psychology 27, 552-565

Woods, G.S. (1998). A Study of Self-Concept as it Relates to Academic Achievement and Gender in Third Grade Students. A Thesis Submitted in partial fulfillment of the requirements of the Master of Arts Degree in the Graduate Division of Rowan University, New Jersey, USA.

Yick, A.G. (2000).Predictors of Physical Spousal/Intimate Violence in Chinese American Families.Journal of Family Violence, Vol. 15, No. 3

Zimmerman, B.J. (1990). Self-Regulated Learning and Academic Achievement: An Overview. Educational Psychologist, 25(1), 3-17

Zuckerman, M. and Tsai, F.F. (2005).Costs of self-handicappingJournal of Personality 73(2), 411-442 